\title{
Leaf area and epicuticular wax content of Sida spp. ${ }^{1}$
}

\author{
Viviane Cristina da Cunha², José Barbosa dos Santos ${ }^{3}$, Cintia Gonçalves Guimarães ${ }^{2}$, Karina Guimarães Ribeiro ${ }^{3}$, \\ Roqueline Rodrigues Silva de Miranda ${ }^{4}$, Daniel Valadão Silva ${ }^{2}$, Germani Concenço ${ }^{5}$
}

\begin{abstract}
Morpho-physiological characteristics and chemical composition are directly related to superior competitive ability of crops. This study intended to make a comparative analysis of dry matter production, leaf area and amount of epicuticular wax of three species of Sida spp: S. urens L., S. rhombifolia L. and S. spinosa L. Plants were collected at three growth stages: V1: stage described as up to 10 fully expanded leaves; V2: between 11 leaves and flowering; and $\mathrm{R}$ : after flowering. At stages $\mathrm{V}_{2}$ and $\mathrm{R}$, the highest number of leaves was recorded for $S$. rhombifolia, followed by $S$. spinosa at $\mathrm{V}_{2}$ and $S$. urens at $\mathrm{R}$. These results were relatively proportional to leaf area for all species. S. spinosa at the vegetative stage produced the highest values of specific leaf area (SLA), with no significant differences between species at the stage $R$. The amount of wax per unit of leaf area between species at the same developmental stage was significantly different only at the reproductive stage, where $S$. spinosa produced 23.18 and 6.23 fold more wax than $S$. urens and $S$. rhombifolia respectively. Between the growth stages of each species, there was decrease in the amount of wax with plant age and increase in leaf area (AFE), number of leaves and dry matter. The leaves of the Sida species exhibit different characteristics and this information can be used to optimize the use of herbicides in the control of these weeds.
\end{abstract}

Key words: Sida rhombifolia L., Sida spinosa L., Sida urens L., weeds.

\section{RESUMO}

\section{Área foliar e conteúdo de cera epicuticular de Sida spp.}

Características morfofisiológicas e composições químicas estão diretamente relacionadas com a maior habilidade competitiva das culturas. O objetivo deste trabalho foi realizar análise comparativa da produção de matéria seca, de área foliar e de quantidade de cera epicuticular de três espécies de Sida spp.: Sida urens L., Sida rhombifolia L. e Sida spinosa L. Essas espécies foram coletadas em três estádios fenológicos, caracterizados como V1: formação de até dez folhas completamente expandidas; V2: entre 11 folhas e antes do florescimento, e R: após florescimento. Verificou-se, para os estádios V2 e R, maior número de folhas para a espécie Sida rhombifolia, seguida por S. spinosa em V2 e $S$. urens em R. Esses resultados foram relativamente proporcionais à área foliar para todas as espécies. $S$. spinosa, na fase vegetativa, produziu os maiores valores de área foliar específica (AFE), não se observando diferenças entre as espécies avaliadas no estádio caracterizado por R. Para a quantidade de cera por unidade de área foliar, entre

\footnotetext{
Received:10/01/2012; Accepted:29/11/2013

${ }^{1}$ Part of first author's Master's dissertation.

${ }^{2}$ Agronomist Engineer, Master of Science. Universidade Federal dos Vales do Jequitinhonha e Mucuri, Campus JK, Rodovia MGT 367, Km 583, 5000, Alto da Jacuba, Diamantina, Minas Gerais, Brasil.vicunhax@yahoo.com.br; cintiagguimaraes@yahoo.com.br; danielvaladaos@yahoo.com.br (corresponding author).

${ }^{3}$ Agronomist Engineer. Universidade Federal dos Vales do Jequitinhonha e Mucuri, Campus JK, Rodovia MGT 367, Km 583, 5000, Alto da Jacuba, Diamantina, Minas Gerais, Brasil.jbarbosasantos@yahoo.com.br; karina_ufvjm@yahoo.com.br

${ }^{4}$ Chemical Engineer. Departamento de Química, Universidade Federal dos Vales do Jequitinhonha e Mucuri, Campus JK, Rodovia MGT 367, Km 583, 5000, Alto da Jacuba, Diamantina, Minas Gerais, Brasil. roquelinersm@yahoo.com.br

${ }^{5}$ Agronomist Engineer, Doctor of Science. Empresa Brasileira de Pesquisa Agropecuária - Agropecuária Oeste, Rodovia BR 163, Km 253,6, CP 661, 79804-970, Dourados, Mato Grosso do Sul, Brasil. gconcenco@yahoo.com.br
} 
as espécies, num mesmo estádio, verificou-se diferença somente na fase reprodutiva, em que $S$. spinosa produziu valores 23,18 e 6,23 vezes maiores que os encontrados para $S$. urens e S. rhombifolia, respectivamente. Entre os estádios para cada espécie, observou-se decréscimo na quantidade de cera com a idade das plantas e um aumento da área foliar, AFE, do número de folhas e da massa seca. A estrutura foliar das espécies de Sida sp. avaliadas apresenta diferentes características e essas informações podem ser utilizadas para otimizar o uso dos herbicidas no controle dessas plantas daninhas.

Palavras-chave: Sida rhombifolia L., Sida spinosa L., Sida urens L., plantas daninhas.

\section{INTRODUCTION}

The genus Sida comprises more than 170 species and most of them are considered as potential weeds in pastures and annual crops. These species are widely distributed, hard to be controlled and adapted to weak and acid soils, although they develop better in fertile clay soils (Kissmann \& Groth, 2000).

Although botanically similar, species of Sida differ in their susceptibility to herbicides, especially in postemergence application (Albert \& Victoria Filho, 2002 a). The efficiency of herbicides applied to leaves depends on the morphology and physicochemical characteristics of the leaf surface and the presence of adjuvants in the herbicidal solution (Constantin et al., 2007).

Several authors reported that morphological and physiological characteristics such as shoot, root and total dry mass (Wortmann, 1993; Olesen et al., 2004; Bianchi et al., 2006), plant height (Fleck, 1980; McDonald, 2003), leaf area (Wortmann, 1993; Lemerle et al., 1996) and leaf area index (Gibson et al. 2003; Haefele et al., 2004) are directly related to superior competitive ability of crops. Over the past few years, research topics have also been directed to the integrated weed management (Bianco et $a l ., 2008)$ and providing relevant information to the evaluation of characteristics within a species that may interfere with the dynamics of control.

Morphology of plants, especially leaves, influences the amount of herbicide intercepted and retained (Hess \& Falk, 1990), and explains the distinct responses of plant species to several products (Chun et al., 1997). However, plant anatomical and micro-morphological characteristics do not determine how easily these products will be absorbed (Hess \& Falk, 1990). The cuticle or cuticular membrane is the first barrier to the absorption of chemicals applied to the leaves and has been the subject of several studies. Some studies have emphasized its nature as well as the factors influencing its permeability (Holloway, 1982, Bukovac et al., 1990, Albert \& Victoria Filho, 2002 b). Cuticle is the major route of herbicide absorption, which makes the knowledge of this structure of fundamental importance in studies of absorption of these compounds (Procópio et al., 2003).
The deposition of epicuticular wax is continuous until full morphological development of the leaf. The deposition rate depends directly on temperature and light, being inversely proportional to water content in the plant (Skoss, 1955). Water, from atmospheric precipitation, besides causing removal of epicuticular wax, reduces cuticle thickness and consistency, influencing the oxidation and condensation of fatty acids, which are processes involved in cuticle formation (Evans, 1984).

The importance of the genus Sida in agricultural ecosystems highlights the need for basic studies aiming to optimize the effectiveness of practices of weed management. In this way, this work aimed to comparatively analyze the dry mass, leaf area and amount of epicuticular wax in three species of the genus Sida, at three developmental stages.

\section{MATERIAL AND METHODS}

A phytosociological study in areas of pasture held at the Experimental Station of the University of the Jequitinhonha and Mucuri (UFVJM), Curvelo Moura, Minas Gerais, demonstrated the that species of the genus Sida have a high importance value. Thus, on May 2009, samples of three species of this genus were collected (Sida urens, Sida rhombifolia and Sida spinosa) at three developmental stages (V1: up to 10 fully expanded leaves; V2: between 11 leaves and flowering and R: after flowering). Plants from the spontaneous vegetation were collected randomly and subjected to 9 treatments resulted from a combination of the three species and three sampling stages, each one with six replications.

Plants were cut close to the ground and brought to the Chemistry Lab at UFVJM for evaluation of leaf area, shoot dry mass and extraction and quantification of wax. Plants were kept in a cooler with ice to avoid dehydration and weight loss during transportation between field and laboratory.

Leaf area estimation was performed by scanning detached leaves and digitalizing into the software Digital Determinator Areas (DAA). Leaf dry mass was weighed in a digital scale with $0.0001 \mathrm{~g}$ precision, withdrawing a 
sample for quantification of epicuticular wax. For that purpose, in a petri dish, samples from each treatment were dried $\left(65^{\circ} \mathrm{C}\right.$ for 72 hours) and immersed in $100 \mathrm{~mL}$ of chloroform for 30 seconds (Hamilton, 1995). The solution (chloroform, wax and impurities) was filtered through Isofar filter paper (12.5 cm diameter) and transferred to a flask attached to a Rotavapor, for evaporation and recovery of most of the chloroform. The remaining solution containing the wax was transferred to previously weighed test tubes. After complete chloroform evaporation, the tubes were weighted again to obtain the content of epicuticular wax expressed in $\mathrm{mg} / \mathrm{cm}^{2}$.

The remaining leaves were also measured using the same procedure described for the samples used for the determination of leaf area. Based on these data, the specific leaf area (SLA) and wax content per unit area $\left(\mathrm{mg} / \mathrm{cm}^{2}\right)$ were determined.

Data was subjected to tests of normality and homogeneity of variances, and then to analysis of variance and the means, when significant, were compared by Duncan's multiple range test at $5 \%$ probability.

\section{RESULTS AND DISCUSSION}

The highest leaf number was recorded at the vegetative stage V2 for Sida spinosa and reproductive stage $\mathrm{R}$ for the other species (Table 1). The influence of this variable in leaf area was evaluated at the final stage and produced similar results, e.g. more leaf area for $S$. rhombifolia, greater than $200 \mathrm{~cm}^{2}$, and $171.49 \mathrm{~cm}^{2}$ for $S$. urens. S. spinosa showed lower leaf area, around $20 \mathrm{~cm}^{2}$. The highest leaf number for $S$. spinosa can be explained by the relatively smaller leaf size of this species during V2 than S. urens (Lorenzi, 2006). Leaf number of S. urens and S. rhombifolia increased 8.46 and 3.48 fold between the stages V2 and R, providing additional photosynthates for fruit formation (Streck et al., 2005).

Pierce et al. (1994) observed that the specific leaf area (SLA - ratio between leaf area and leaf dry mass) is an important ecophysiological characteristic for the understanding of plant carbon-water relations. It is also an important factor from a physiological standpoint because it describes the allocation of leaf biomass per unit area, reflecting the capacity and efficiency in conserving nutrients by fast biomass accumulation (Poorter $\&$ Garnier, 1999). The highest SLA value for $S$. spinos $a$ was recorded at the vegetative stage (Table 2). At the reproductive stage $(\mathrm{R})$, no difference was found for SLA between species, with mean equal to $113.24 \mathrm{~cm}^{2} / \mathrm{g}$ (Table 2). Thus, results could help in understanding the aggressive competitive ability of $S$. spinosa in crops like cotton (Chandler, 1977) and soybean (Payne and Oliver, 2000).

Differences in the amount of wax per unit of leaf area between species at the same stage only occurred at the reproductive stage, with $S$. spinosa having more wax than the other species (Table 2). The amount of wax in S. spinosa at the reproductive stage was 6-23 times larger than for those found for $S$. urens and $S$. rhombifolia respectively. In general, the amount of wax decreased with plant age. This result is contrary to expectations, since it was believed that the difficulty in controlling the Sida sp., in more advanced stages of development, was due to increased layers of wax. However, as observed by Monqueiro et al. (2004), the composition of the epicuticular wax layer itself is longer related to this difficulty in the chemical control of some weeds, than its quantity.

Sida urens and S. rhombifolia had a reduction in the amount of wax as plants advanced from the developmental stage V2 to R (Table 2). Several other studies show evidences that older leaves are less capable of controlling water loss than young leaves, as observed in banana (Musa spp.) by Costa et al. (2009). Alves et al. (1990), studied the effect of simulated acid rain on the amount of epicuticular wax of soybean plants and found that regardless of irrigation there was a decrease in epicuticular wax content with elapsed days. In this study, we found that the decrease in wax accumulation was significantly lower in S. spinosa, which is likely the cause for the high aggressive competitive ability of this species in cotton and soybean crops, as previously reported. In studies with sugarcane varieties, higher amounts of epicuticular wax were found in varieties classified as more tolerant to

Table 1. Total number of leaves and leaf area of three species of the Genus Sida, sampled at three distinct phenological stages

\begin{tabular}{|c|c|c|c|c|c|c|}
\hline \multirow{3}{*}{ Species } & \multicolumn{6}{|c|}{ Phenological Stages $^{1 /}$} \\
\hline & \multicolumn{3}{|c|}{$N^{o}$ of Leaves } & \multicolumn{3}{|c|}{ Leaf Area $\left(\mathrm{cm}^{2}\right)$} \\
\hline & V1 & V2 & $\mathbf{R}$ & V1 & $\mathbf{V 2}$ & $\mathbf{R}$ \\
\hline Sida urens & $8 \mathrm{Ba}$ & $15 \mathrm{Bc}$ & $82 \mathrm{Ab}$ & $5.80 \mathrm{Ba}$ & $20.25 \mathrm{Ba}$ & $171.49 \mathrm{Ab}$ \\
\hline Sida spinosa & $4 \mathrm{Ba}$ & $51 \mathrm{Ab}$ & $28 \mathrm{Bc}$ & $1.71 \mathrm{Aa}$ & $13.45 \mathrm{Aa}$ & $20.01 \mathrm{Ac}$ \\
\hline Sida rhombifolia & $3 \mathrm{Ca}$ & $103 \mathrm{Ba}$ & 308 Aa & $1.13 \mathrm{Ca}$ & $58.67 \mathrm{Ba}$ & $204.23 \mathrm{Aa}$ \\
\hline $\mathrm{CV}(\%)$ & 24.00 & 32.80 & & & & \\
\hline
\end{tabular}

1/V1: From plant formation until up to 10 completely expanded leaves; V2: between 10 leaves and before flowering; R: after flowering. Means followed by the same letter in the rows (capital letters) and columns (small letters), for each parameter, are not significantly different by the DMRT test ant $5 \%$ probability. 
herbicides (Ferreira et al., 2005). It is therefore possible that the results of lower susceptibility of S. spinosa to some herbicides can be explained by a high wax content compared to other species of the genus Sida. Beyers et al. (2002), evaluating the effectiveness of the herbicide flumicloracpentyl, reported that its addition to ammonium glufosinate did not significantly improve the control of S. spinosa.

Constantin et al. (2007) found that among several herbicides tested for control of four species of Sida ( $S$. rhombifolia, S. spinosa, S. cordifolia and S. glaziovii), fomensafen and lactofen, even with adjuvant, showed the lowest control rates for S. spinosa. However, the same authors found that the herbicide flumiclorac-pentyl was an excellent option, successfully controlling this species.

Studies (Albert \& Victoria Filho, 2002a; 2002b) evaluating the leaf surface of three species of Sida (S. rhombifolia, $S$. cordifolia and S. glaziovii) found that $S$. rhombifolia had higher amounts of randomly orientated epicuticular striate wax and that this trait was found more abundantly at the adaxial side, suggesting further studies on this characteristic to allow a correlation with herbicide tolerance.

For Schmidt et al. (1981), the epicuticular layer of young leaves presents higher polarity, which allows the passage of large amounts of hydrophilic compounds such as some herbicides. Grover and Cessna (1991) reported evidences that penetration of herbicides decreases as leaf age increases. For Silva \& Silva (2007), the absorption of herbicides is not necessarily related to the thickness or weight of the cuticle, but to its degree of impermeability which can be attributed to changes in composition or increases in formation of waxes.

It is possible to infer that the competitive ability of $S$. spinosa is associated to the production of epicuticular wax, instead of mass accumulation. Thus, the higher proportion of wax in relation to the rest of the dry mass of leaves would be an important factor in tolerance to the penetration of herbicides. Chun et al. (2001), evaluating the absorption of oxyfluorfen by two species of wheat, found that in average $65 \%$ of the herbicide was retained at the epicuticular wax, even after 120 hours post-application. Regarding the infestation of pastures, assuming intensive use of 2,4$\mathrm{D}$ alone or mixed with picloram, the lower wax content in $S$. urens would help elucidating the best results of control for this species relatively to $S$. spinosa (Lorenzi, 2006).

Table 2. Specific leaf area (SLA) and epicuticular wax content of three species of the Genus Sida, sampled at three distinct phenological stages

\begin{tabular}{|c|c|c|c|c|c|c|}
\hline \multirow[t]{3}{*}{ Species } & \multicolumn{6}{|c|}{ Phenological Stages $^{1 /}$} \\
\hline & \multicolumn{2}{|c|}{ SLA $\left(\mathrm{cm}^{2} / \mathrm{g}\right)$} & \multirow[b]{2}{*}{$\mathbf{R}$} & \multicolumn{3}{|c|}{$\operatorname{Wax}\left(\mathbf{m g} / \mathrm{cm}^{2}\right)$} \\
\hline & V1 & V2 & & V1 & $\mathbf{V 2}$ & $\mathbf{R}$ \\
\hline Sida urens & $87.47 \mathrm{Bb}$ & $94.97 \mathrm{Bb}$ & $107.04 \mathrm{Aa}$ & $3.28 \mathrm{Aa}$ & $1.31 \mathrm{Ba}$ & $0.11 \mathrm{Cb}$ \\
\hline Sida spinosa & $111.57 \mathrm{Aa}$ & $130.68 \mathrm{Aa}$ & $130.01 \mathrm{Aa}$ & $4.92 \mathrm{Aa}$ & $2.72 \mathrm{Ba}$ & $2.55 \mathrm{Ba}$ \\
\hline Sida rhombifolia & $97.40 \mathrm{Aab}$ & $91.32 \mathrm{Ab}$ & $102.66 \mathrm{Aa}$ & $4.16 \mathrm{Aa}$ & $4.08 \mathrm{Ba}$ & $0.41 \mathrm{Bb}$ \\
\hline $\mathrm{CV}(\%)$ & 17.09 & 32.11 & & & & \\
\hline
\end{tabular}

1/V1: From plant formation until up 10 completely expanded leaves; V2: between 10 leaves and before flowering; R: after flowering. Means followed by the same letter in the rows (capital letters) and columns (small letters), for each parameter, are not significantly different by the DMRT test ant $5 \%$ probability.

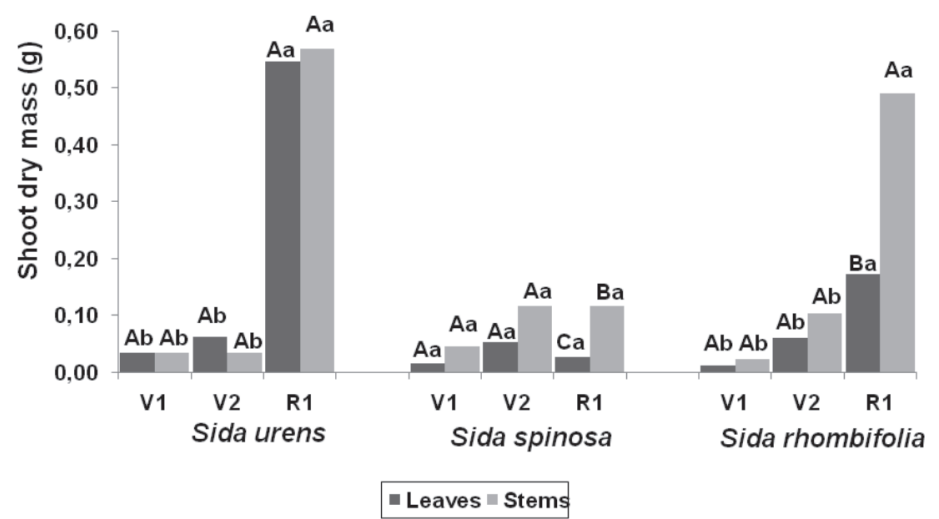

Figure 1. Shoot dry mass (leaves and stems) of three Sida species (Sida urens, S. spinosa and S. rhombifolia).

*Means followed by the same capital letters indicate that the species of Sida did not differ in the amount of shoot dry mass in different vegetative stages and by the same lower small letters indicate that different stages do not differ in the accumulation of shoot dry mass by DMRT test ant $5 \%$ probability 
S. urens and S. rhombifolia showed higher shoot dry mass mainly due to the accumulation of biomass in stems (Figure 1). Among the stages evaluated for each species, no difference was observed for biomass accumulation in S. spinosa. However, for S. urens, the accumulation of biomass was five times higher in the reproductive stage compared to the vegetative.

\section{CONCLUSIONS}

The number of leaves, leaf area, quantity of epicuticular wax and dry matter vary with the stage of development of each species of Sida spp. evaluated.

Sida spinosa presented greater values than Sida rhombifolia and Sida urens of specific leaf area at the vegetative stage and of wax at the reproductive stage, which can be related to its competitive ability and lower susceptibility to some herbicides.

\section{ACKNOWLEDGEMENTS}

The authors thank the Conselho Nacional de Desenvolvimento Científico e Tecnológico (CNPq), Fundação de Amparo à Pesquisa do Estado de Minas Gerais (FAPEMIG) and Coordenação de Aperfeiçoamento de Pessoal de Nível Superior (CAPES) for the financial support to this work.

\section{REFERENCES}

Albert LHB \& Victoria Filho R (2002a) Características Morfológicas da Cutícula Foliar e Efeitos de Adjuvantes no Controle Químico de Três Espécies de Guanxumas. Ciência e Agrotecnologia, 26:888-899.

Albert LHB \& Victoria Filho R (2002b) Micromorfologia Foliar de Espécies de Sida spp. (guanxumas). Planta daninha, 20:337342 .

Alves PLCA, Oliva MA, Cambraia J \& Sant'anna R (1990) Efeitos da chuva ácida simulada e de um solo de Cubatão (SP) sobre parâmetros relacionados com a fotossíntese e a transpiração de plantas de soja. Revista Brasileira de Fisiologia Vegetal, 2:0714.

Beyers JT, Smeda RJ \& Johnson WG (2002) Weed managements programs in glufosinate-resistant soybean (Glycine max). Weed Technology, 16:267-273.

Bianchi MA, Fleck NG \& Federizzi LC (2006) Características de plantas de soja que conferem habilidade competitiva com plantas daninhas. Bragantia, 65:623-632.

Bianco S, Carvalho LB \& Bianco MS (2008) Estimativa da área foliar de Sida cordifolia e Sida rhombifolia usando dimensões lineares do limbo foliar. Planta daninha, 26:807-813.

Bukovac MJ, Petracek PD, Fader RG \& Morse RD (1990) Sorption of organic compounds by plant cuticle. Weed Science, 38:289298 .

Chandler JM (1977) Competition of spurred anoda (Anoda cristata), velvetleaf (Abutilon theophrasti), prickli sida (Sida spinosa) and venice mallow (Hibiscus trionum) in cotton. Weed Science, 25:151-158.
Chun JC, Ma SY, Kim SE \& Lee HJ (1997) Physiological responses of Rehmannia glutinosa to paraquat and its tolerance mechanisms. Pesticide Biochemistry and Physiology, 59:5163

Chun JC, Lee HJ, Lim SJ, Kim SE \& Guh JO (2001) Comparative Absorption, Translocation, and Metabolism of Foliar- Applied Oxyfluorfen in Wheat and Barley. Pesticide Biochemistry and Physiology, 70:118-125.

Constantin J, Oliveira JRRS, Kajihara LH, Arantes JGZ, Cavalieri SD \& Alonso DG (2007) Controle de diferentes espécies de guanxuma com aplicações sequenciais de flumicloracpentil. Acta Scientiarum Agronomy, 29:475-480.

Costa FHS, Pereira JES, Pasqual M, Castro EM \& Santos AM (2009) Perda de água e modificações anatômicas em folhas de plantas de bananeiras micropropagadas durante a aclimatização. Ciência Rural, 39:742-748.

Evans LS (1984) Botanical aspects of acidic precipitation. The Botanical Review, 50:449-490.

Ferreira EA, Demuner AJ, Silva AA, Santos JB, Ventrella MC, Marques AE \& Procópio SO (2005) Composição química da cera epicuticular e caracterização da superfície foliar em genótipos de cana-de-açúcar. Planta daninha, 23:11-619.

Fleck NG (1980) Competição de azevém (Lolium multiflorum L.) com duas cultivares de trigo. Planta daninha, 3:61-67.

Gibson KD, Fischer AJ, Foin TC \& Hill JE (2003) Crop traits related to weed suppression in water-seeded rice (Oryza sativa L.). Weed Science, 51:87-93.

Grover R \& Cessna AJ (1991) Environmental chemistry of herbicides. Bocca Raton, CCR Press. 302p.

Haefele SM, Johnson DE, Bodj DM, Wopereis MCS \& Miezan KM (2004) Field screening of diverse rice genotypes for weed competitiveness in irrigated lowland ecosystems. Field Crops Research, 88:39-56.

Hamilton RJ (1995) Waxes: chemistry, molecular biology and functions. Edinburgh, Orly Press. 145p.

Hess FD \& Falk RH (1990) Herbicide deposition on leaf surfaces. Weed Science, 38:280-288.

Holloway PJ (1982) Structure and histochemistry of plant cuticular membranes: an overview. In: Cutler DF, Alvin KL \& Price C (Eds.) The plant cuticle. London, Academic Press. p.01-32.

Kissmann KG \& Groth D (2000) Plantas infestantes e nocivas. São Paulo, BASF. 725p.

Lemerle D, Verbeek B, Cousens RD \& Coombes NE (1996) The potential for selecting wheat varieties strongly competitive against weeds. Weed Research, 36:505-513.

Lorenzi H (2006) Manual de Identificação e Controle de Plantas Daninhas: plantio direto e convencional. $6^{\text {a }}$ ed. Nova Odessa, Instituto Plantarum. 336p.

McDonald GK (2003) Competitiveness against grass weeds in field pea genotypes. Weed Research, 43:48-58.

Monquero PA, Christoffoleti PJ, Matas JA, \& Heredia A (2004) Caracterização da superfície foliar e das ceras epicuticulares em Commelina benghalensis, Ipomoea grandifolia e Amaranthus hybridus. Planta Daninha, 22:203-210.

Olesen JE, Hansen PK, Berntsen J \& Christensen S (2004) Simulation of above-ground suppression of competing species and competition tolerance in winter wheat varieties. Field Crops Research, 89:263-280.

Payne SA \& Oliver LR (2000) Weed Control Programs in Drilled Glyphosate-Resistant Soybean. Weed Technology, 14:413-422.

Rev. Ceres, Viçosa, v. 61, n.2, p. 172-177, mar/abr, 2014 
Pierce LL, Running SW \& Walker J (1994) Regional scale relationships of leaf area index to specific leaf area and leaf nitrogen content. Ecological Applications, 4:313-321.

Poorter H \& Garnier E (1999) Ecological significance of inherent variation in relative growth rate and its components. In: Pugnaire F \& Valladares F (Eds.) Handbook of functional Plant Ecology. New York, Marcel Dekker. p.81-120.

Procópio SO, Silva EAM, Silva EAM \& Ferreira EA (2003) Anatomia foliar de plantas daninhas do Brasil. Viçosa, Universidade Federal de Viçosa. 118p.

Schmidt R, Mondani J, Ziegenhagen E \& Dose K (1981) Highperformance liquid chromatography of the mycotoxins sterigmatocystin and its application to the analysis of mouldy rice for sterigmatocystin. Journal of Chromatography, 207:435438.
Silva AA \& Silva JF (2007) Tópicos em Manejos de Plantas Daninhas. Viçosa, Editora UFV. 367p.

Skoss JD (1955) Structure and composition of plant cuticule in relation to environmental factors and permeability. Botanical Gazette, 11:55-72.

Streck NA, Bellé RA, Rocha EK \& Schuh M (2005) Estimating leaf appearance rate and phyllochron in safflower (Carthamus tinctorius L.). Ciência Rural, 35:1448-1450.

Wortmann CS (1993) Contribution of bean morphological characteristics to weed suppression. Agronomy Journal, 85:840843 . 